\title{
EFFECTIVENESS OF A MICROWAVE FLUIDISED BED DRYER IN ERADICATION OF SEED-BORNE BOTRYTIS GREY MOLD OF LENTIL
}

\author{
S. Taheri ${ }^{1}$, G. Brodie ${ }^{2}$, D. Gupta ${ }^{3}$, \\ 1,2,3 School of Food and Agriculture, Faculty of Veterinary and Agricultural Science, \\ Melbourne, Victoria, Australia \\ Isaeideh.taheri@gmail.com; ${ }^{2}$ grahamb@unimelb.edu.au
}

Keywords: Microwave Fluidized Bed, lentil, Botrytis Grey Mold

\begin{abstract}
A single mode microwave cavity, with a $2.45 \mathrm{GHz}$ microwave source, was modified to have a microwave fluidized bed and its potential to eliminate Botrytis grey mold (BGM) pathogen of lentil seeds was evaluated. Air speed was maintained at a constant value and was just enough to fluidize $100 \mathrm{~g}$ of red lentil seeds in the sample holder. Two wet-based (w.b.) seed moisture contents (MC) of $10.5 \%$ and $18.5 \%$ were prepared and the process parameters were selected as air temperature at 50 and $60^{\circ} \mathrm{C}$; microwave power at $0,300,400 \mathrm{~W}$ for $18.5 \%$ $\mathrm{MC}$ and $0,400,500 \mathrm{~W}$ for $10.5 \% \mathrm{MC}$; and exposure times of 5 and $10 \mathrm{~min}$. The effect of the process parameters on seed moisture loss, seed germination, the electrical conductivity of seed soaking water and the percentage of infected seeds (IS\%) were analyzed. The most effective factors on moisture loss, after seed moisture content, was exposure time, followed by microwave power and air temperature. While the final bed temperature was mostly affected by air temperature, and then by microwave power. Furthermore, based on general full factorial regression and Pareto chart of standardized effects, moisture content had a major influence on the reduction of IS\%. Seed pathogen inoculum reduction, without significant seed viability loss, was obtained by applying microwave power of $300 \mathrm{~W}$ and set air temperature of $60^{\circ} \mathrm{C}$ (actual inlet air temperature of $57 \pm 1^{\circ} \mathrm{C}$ ) on seeds with $\mathrm{MC}$ of $18.5 \%$ for $10 \mathrm{~min}$. This gave a $27 \%$ reduction in IS\%, from $82 \%$ to $55 \%$. Thus, these results showed that applying microwave fluidized bed dryer was able to reduce BGM pathogen in lentil seeds and it could be considered as part of integrated disease management.
\end{abstract}

\section{Introduction}

Botrytis cinerea $(B C)$ is one of the important seed-borne pathogens causing botrytis grey mold (BGM) disease of chickpea and lentil crops, one of the economically important seedborne diseases in Australia. It can survive in the form of micro and macroconidia, mycelium, sclerotia and chlamydospores (Yigal Elad 2007). Lindbeck, Bretag et al. (2009) showed that $\mathrm{BC}$ is mostly located externally on lentil and chickpea seeds. They mentioned that seeds, which are infected during early stages of growth, may have an internal infection and will be discoloured and shrivelled, so they could be recognized by their appearance. However, those infected later, close to the harvest time, do not have any symptoms and might be used for sowing in the next season. The later seeds are mostly externally infected.

BGM control in lentil crop consists of integrated management including the application of resistant cultivars, healthy seeds, biological agents, seed treatment, foliar treatment with fungicides and cultural practices (Beniwal and Trapero-Casas 1994, Yigal Elad 2007). Lentil varieties grown in Australia do not have complete resistance against BGM and need fungicide application to control the disease (Lindbeck, Bretag et al. 2008). Therefore, using chemicals for seed and foliar treatments has remained the easiest and the most popular way of BGM control in this crop. However, there are still concerns about BGM pathogen's ability to develop resistance as well as environmental and health impacts due to over usage of 
fungicides (Fillinger and Elad 2016). There have been some attempts to find a physical treatment for control or eradication of BGM pathogen. Burgess (1997) showed that BC is mostly present externally in chickpea seeds and can be controlled by moist heat at $45^{\circ} \mathrm{C}$ for $10 \mathrm{~min}$ or $50^{\circ} \mathrm{C}$ for $5 \mathrm{~min}$. These treatments decreased seed infection to 2.5 and $0 \%$ respectively with no adverse effect on the seed germination and seedling emergence. However, the same treatment on the freshly harvested seeds reduced the infection to $18 \%$, which could be the result of initial inoculum or changes in heat tolerance of the pathogen during treatment time. They also indicated that infected seeds did not necessarily have any visual symptoms to distinguish them from healthy seeds. This highlighted the need for seed testing. Marquenie, Lammertyn et al. (2002) applied UV-C, thermal treatment and their combination to inactivate spores of $\mathrm{BC}$. They used first-order kinetic models to describe the inactivation of the spore, with temperature and UV dose as the independent factors for thermal and UV-C treatment respectively. They observed that there was no survival of conidia at $45^{\circ} \mathrm{C}$ after $15 \mathrm{~min}$ and at $48^{\circ} \mathrm{C}$ after $5 \mathrm{~min}$. It was concluded that the combination of UV and thermal treatment allowed inactivation at lower temperature and lower UV doses. Nevertheless, there is still a lack of information on a proper physical method for elimination of BC from important legume crop seeds, such as lentil.

The objective of this experiment was to investigate the possibility of control or eradication of seed-borne $B C$ from lentil seeds in a microwave fluidized-bed drier. For this purpose, the effect of different process parameters on moisture loss, temperature, seed viability and infected seed percentage (IS\%) were investigated.

\section{Materials and Methods}

\section{Lentil Seeds preparation}

Red lentil seeds (Type Bolt) were purchased from PBseeds Co, Horsham, Victoria, Australia. The initial moisture content was measured by drying $10 \mathrm{~g}$ of unground seeds at $130^{\circ} \mathrm{C}$ for $20 \mathrm{~h}$ (Tang and Sokhansanj 1991). The 100 -seeds weight was $4.27 \pm 0.09 \mathrm{~g}$ and their average diameter and thickness, which were measured using a digital calliper, were $5 \pm$ 0.19 and $2.4 \pm 0.14 \mathrm{~mm}$ (average of twenty seeds). To reach the desired moisture content, a calculated volume of sterilised distilled water was added to a known amount of dried seeds in a resealable polyethylene bag and after thorough shaking, they were kept in a refrigerator for at least one week and used in the experiment within one month, to make sure the seed viability did not change in storage, especially for moisture contents of above $17 \%$. During the first week of storage, before the start of the experiment, seeds were mixed two times per day to make sure moisture was uniformly distributed among the seeds.

\section{Inoculation of lentil seeds}

Botrytis cinerea (174/02) spores, isolated from lentil seeds in Australia in 2002, were provided by Dr. Jenny Davidson, from the South Australian Research and Development Institute (SARDI). The isolate was subcultured on potato dextrose agar (PDA) and incubated at $22^{\circ} \mathrm{C}, 12 \mathrm{~h} / 12 \mathrm{~h}$ dark/light cycle under fluorescent (OSRAM TLD/18W) and near ultraviolet (UV) lights (PHILIPS BLB/18W). After two weeks, when the cultures were full of conidia, the spore solution was prepared by flooding with sterilized distilled water (SDW) (with $0.01 \%$ tween 20 ) on plates of BC on PDA and harvesting the spores by gently rubbing the surface of the culture using a glass rod. About $100 \mathrm{ml}$ of spore solution, with $10^{5}-10^{6}$ spore $/ \mathrm{ml}$, was obtained from two plates.

Inoculation of the lentil seeds was done according to the method described by Burgess, Bretag et al. (1997). Briefly, lentil seeds were surface sterilized with Sodium Hypochlorite $(1 \%)$ for one minute, followed by rinsing three times with sterile distilled water. Sterilized 
seeds were placed on a sterilized cheesecloth in a safety biological cabinet to let the excess water dry before putting them inside an autoclaved Scott bottle. The spore solution was diluted with sterilized distilled water to reach a concentration of $10^{4}-10^{5} \mathrm{spore} / \mathrm{ml}$. This solution was poured onto the lentil seeds in the Scott bottle to reach $10^{3}$ spores $/ \mathrm{seed}$. The spore solution's volume was enough to wet all the seeds (for red lentil $25 \mathrm{ml} / 100 \mathrm{~g}$ ). After pouring the spore solution, the bottle was tightly closed and mixed thoroughly and left overnight in the dark to make sure the spores are attached to the seeds. The bottle was shaken two times to make sure the spores are attached to all the seeds. On the next day, the inoculated seeds were spread on sterilized aluminum foil in a biological safety cabinet and weighed regularly to reach the required moisture content of 10.5 and $18.5 \%(\mathrm{wb})$. To reach the initial moisture content, they were left for three nights. After reaching the desired moisture contents, seeds were transferred in the Scott bottles, kept at $5^{\circ} \mathrm{C}$ and used in the experiment within one month. Before each treatment, seeds were taken out of the refrigerator and left overnight in the room to reach room temperature.

\section{Microwave fluidized bed system and treatment of the lentil seeds}

Schematic of the system is illustrated in Figure 1.

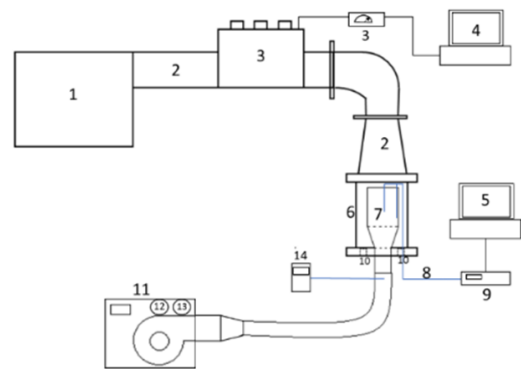

Figure 1 Microwave fluidized-bed system for drying and disinfection of particles, 1magnetron, 2- waveguide, 3- three-stub tuner, 4- absorbed power monitoring, 5- data acquisition system and microwave power control, 6- microwave cavity, 7- sample holder (fluidized bed), 8- fibre optic probes, 9- temperature monitor, 10- vents, 11- air blower and heater, 12- air speed potentiometer, 13- air temperature potentiometer, 14- inlet air temperature monitor

For each treatment, $90 \mathrm{~g}$ of healthy seeds were mixed with $10 \mathrm{~g}$ of inoculated seeds, which were marked with a red marker. The total of $100 \mathrm{~g}$ of seeds was transferred into the sample holder with a perforated bottom. Three fiber optic sensors were placed in the hot spot (top center of the bed), the cold spot (corner of the cylindrical sample holder) and at the bottom of the sample holder, where the air enters. This was considered as inlet air temperature. Hot and cold spots were obtained from the results of simulation of microwave power distribution in $\mathrm{XFdtd}^{\circledR}$ 7.5.0 (Remcom, Inc., State College, PA) using dielectric properties (Taheri, Brodie et al. 2018) and physical properties (Tang, Sokhansanj et al. 1991, Gharibzahedi, Ghahderijani et al. 2014) of red lentil seeds. Autodesk Inventor Professional 2017 (Autodesk Inc., USA) was used to design the 3-D geometry of lentil seeds with dimensions of 6.8 and $2.4 \mathrm{~mm}$ and $36 \mathrm{~mm}$ bed thickness (15 layers of lentil seeds), which was then placed in the sample holder inside the microwave cavity to perform the simulation.

Here, the real dimensions of the lentil seeds were not considered, because the real dimensions were too small, and the computer's space was not enough to solve the finite- 
difference-time-domain equations. However, the thickness of $36 \mathrm{~mm}$ was the same as $100 \mathrm{~g}$ of red lentils at $18.5 \% \mathrm{MC}$, which was used in the experiment. The amount of sample was selected, firstly, for having a proper power density, which did not increase the hot spot temperature quickly and harm the seeds and secondly, for having a thickness less than the penetration depth of the microwave at $2450 \mathrm{MHz}$ in lentil seeds (Taheri, Brodie et al. 2018). As the seeds are fluidized by hot air, fiber optic probs did not show the real seed surface temperatures and it is assumed that the measured temperatures are an average of air and seeds surface temperature, which is henceforth called bed temperature. Air speed was adjusted to fluidize the bed. Turning the potentiometer, a fracture below $560 \mathrm{l} / \mathrm{min}$ turned the fluid bed into a static bed.

\section{Evaluation of lentil seed viability and vigour after treatments}

Seed viability was examined by the standard germination test. Twenty seeds per replicate and a total of 60 seeds per treatments were placed on Whatman filter paper no.1 in 9-cm Petri dishes. Each plate contained 10 seeds which were wetted by $4 \mathrm{ml}$ of sterilized distilled water. Germination of the seeds was examined after two and five days. Vigour of the seeds was evaluated by measuring electrical conductivity (EC) of the seed soaking water according to ISTA ( 2016). Following each treatment, 50 lentil seeds were counted and, accurately weighed and placed in $250-\mathrm{ml}$ Erlenmeyer flasks. One hundred $\mathrm{ml}$ distilled water was poured in each container to cover the seeds and provide enough depth to soak the seeds. The containers' heads were covered with aluminium foil and after $24 \mathrm{~h} \pm, 15$ minutes electrical conductivity of the soaking water was measured using an EC probe (model HI98304, HANNA Instruments Inc.; Melbourne, Australia) with a resolution of $0.01 \mathrm{mS} / \mathrm{cm}$ and accuracy of $\pm 2 \%$ F.S. at $25^{\circ} \mathrm{C}$. The result was calculated according to equation (1). Distilled water was used as a blank for background reading of conductivity and the test was carried out in triplicate.

$$
\begin{aligned}
\text { Conductivity }\left(\mu S \mathrm{~cm}^{-1} \mathrm{~g}^{-1}\right) \\
\text { conductivity reading }\left(\frac{\mu S}{\mathrm{~cm}}\right)-\text { background reading }
\end{aligned}
$$

\section{Evaluation of BGM pathogen viability after treatments}

Botrytis selective media (BSM) was prepared according to Burgess (1997) and Edwards and Seddon (2001). The media contained (g/l): glucose 2; PDA 5; Agar 10; tannic acid 5; Ridomil 0.02; Pentachloronitrobenzene (PCNB) solution 0.5\% in ethanol 4; Zineb 0.00091; and streptomycin sulphate 0.1. a mixture of glucose. The PDA and Agar were autoclaved before adding to the rest of the ingredients.

After each treatment, the contaminated seeds, which had been marked, were separated and 30 seeds per replicate with a total of 90 seeds per treatment were subcultured on BSM. The plates were incubated at $23^{\circ} \mathrm{C}$ and after 4 and 10 days were examined to see the pathogen's growth. BC was recognized, based on the appearance of the mycelium and their conidia under microscope (after 2 weeks) as well as the colour change of the selective media to brown, which was the result of tannic acid oxidation.

\section{Evaluation of thermal resistance of the BMC pathogen in a water bath}

To see the susceptibility of the pathogen to thermal treatment at different seed moisture contents, five grams of inoculated lentil seeds at moisture contents of $10.5 \%$ (initial), $12.5 \%$, $14.5 \%, 16.5 \%$ and $18.5 \%(\mathrm{wb})$ were placed inside a resealable polyethylene bag and immersed in a water bath at temperatures $60,65,67,70,75^{\circ} \mathrm{C}$ for $10 \mathrm{~min}$. The seeds were 
sub-cultured on BSM and examined for the percentage of infected seeds after 4 and 10 days. Five-Minute exposure time was also examined for those temperatures, which were effective in $100 \%$ elimination of the pathogens. The results of these treatments helped the selection of the microwave power to treat the seeds with selected moisture content. The powers were selected to raise the seed surface temperatures to those which were lethal to the pathogen so that the bed temperature was at least $5^{\circ} \mathrm{C}$ above these temperatures.

\section{Experimental design and statistical analysis}

To investigate the effect of different process parameters on moisture loss, final temperature, germination, and frequency of pathogen isolation from the seeds or percentage of infected seeds (IS\%), an experiment was designed with four factors, each with 2 or 3 levels and with 3 replications. Factors and levels were selected as follow: moisture content (MC) at 10\% (dry form) and $18 \%$ wet base (wb); air temperature set at 50 and $60{ }^{\circ} \mathrm{C}$; microwave output power at $0,200,300$ for $18 \% \mathrm{MC}$ and $0,400,500$ for $10 \% \mathrm{MC}$; and exposure times of 5 and $10 \mathrm{~min}$. The set air temperature of 50 and $60^{\circ} \mathrm{C}$ was measured as $50 \pm 1$ and $57 \pm 1^{\circ} \mathrm{C}$ at the inlet of the sample holder.

This experiment was set out as a randomized full factorial design in Minitab version 18.1 (Minitab Inc., Pennsylvania, USA). The effect of microwave power, air temperature, exposure time and initial moisture content on final sample temperature, moisture loss, seed viability and percentage of infected seeds were investigated using a general factorial regression and analysis of variance. The most effective factors were found from a Pareto chart of the standardized effects with $\alpha=0.05$. Significant differences from the control were analyzed by one-way analysis of variance. All the statistical analysis was performed in MINITAB Statistical Software version 18.1 (Minitab, Inc., Pennsylvania, USA) and presented data are mean of three replicates.

\section{Results and discussion}

\section{Simulation of power density inside the single mode cavity}

Results of microwave power dissipation inside $100 \mathrm{~g}$ of lentil seeds are shown in Figure 2. As can be seen in the power distribution in the bottom layer of the lentil seeds (Figure 2 (a)), the hot spot of the microwave radiation is predicted to be in the centre of the sample and the cold spot is along the circumference of the cylindrical sample holder. The same distribution was obtained for the top layer of the samples (data not shown). In Figure 2 (b), the maximum and average predicted microwave power density are represented. Here, the maximum microwave power is predicted to be on the top layer of lentil samples and the minimum power is absorbed in the middle layers, $20-25 \mathrm{~mm}$ distance from the top. Therefore, the hot spot was in the centre of the top layer and the cold spot in the corner of the middle layer. Fibre optic probes were placed in these two locations to obtain hot and cold spot temperatures during the treatments. Additionally, hot air was assumed to be evenly distributed in the bed after entering through the perforated plate. 
a

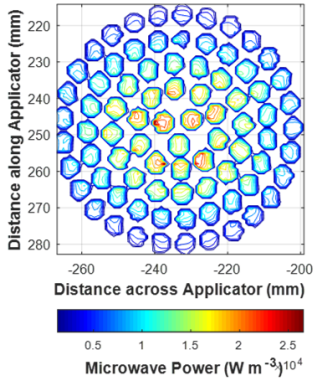

b

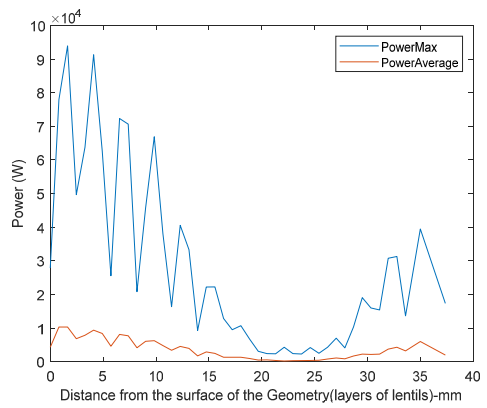

Figure 2 Power dissipation in lentil seeds, the result of simulation; (a) absorbed power distribution in a cross section of the bottom layer of lentil seeds; (b) vertical maximum and average power density in $100 \mathrm{~g}$ of lentil seeds in a cylindrical sample holder $\left(\mathrm{W} / \mathrm{m}^{3}\right)$

\section{Thermal sensitivity of the BGM pathogen in a water bath}

Results of thermal sensitivity of the BGM pathogen on lentil seeds, with different seed MCs, are shown in Figure 3. A 10 min exposure time led to complete eradication of the pathogens from the lentil seeds at $65^{\circ} \mathrm{C}$ for seed $\mathrm{MC}$ of $18.5 \%, 16.5 \%$, and $14.5 \%$, at $70^{\circ} \mathrm{C}$ for $12.5 \%$ seed $\mathrm{MC}$ and at $75^{\circ} \mathrm{C}$ for $10.5 \% \mathrm{MC}$ (Figure $3(\mathrm{a})$ ). A temperature of $65^{\circ} \mathrm{C}$ was also lethal to seed pathogen after 5 min exposure of the contaminated seeds at $18.5 \%$ and $16.5 \% \mathrm{MC}$. However, seeds with MC of $14.5 \%, 12.5 \%$, and $10.5 \%$ required temperatures of $70^{\circ} \mathrm{C}, 75^{\circ} \mathrm{C}$ and $80^{\circ} \mathrm{C}$, respectively to remove the pathogen completely, after $5 \mathrm{~min}$. Taheri, Brodie et al. (2019) also found that Ascochyta blight pathogen of lentil seeds could be reduced more at higher seed moisture content and the same final temperature, by applying microwave treatment.

It must be noted that, here, the seeds were not directly exposed to water, which creates $100 \%$ water activity and lowers the lethal temperature to its minimum. The seeds were sealed in the resealable polyethylene bag and the moisture was not allowed to scape, and water activities could be considered as the seeds water activity at the corresponding moisture content at each temperature. If the exposure time is enough to reach the equilibrium in the closed bags, relative humidity $(\mathrm{RH})$ might be considered close to the water activity.
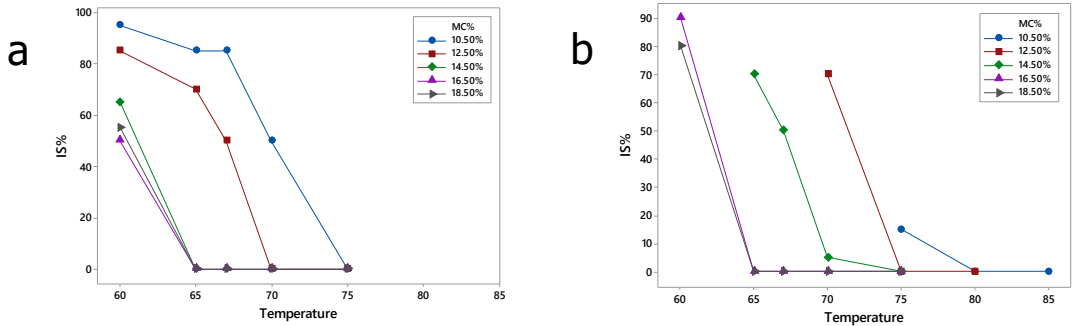

Figure 3 Percentage of botrytis grey mold infected lentil seeds after treatments in a water bath at different temperatures $\left({ }^{\circ} \mathrm{C}\right.$ ) after (a) 10 min and (b) 5 min. IS\%- infected seeds percentage; $\mathrm{MC} \%$-seed moisture content(w.b.) 


\section{Effect of microwave power, air temperature and exposure time on moisture loss and final temperatures of lentil seeds}

Results of the Pareto chart of the standardized effects from general factorial regressions ( $\alpha=$ 0.05) for moisture loss and bed temperature are represented in Figure 4, (a) and (b) respectively. The $\mathrm{x}$-axis of these charts shows the coefficient of each factor in the regression model divided by its standard error. The factors, with the standardized effect of more than 2.04 (red vertical line), have significant effects on the response and the more the standardized effect is, the more effective the factor will be. Pareto chart of moisture loss (Figure 4(a)) suggested that all the factors including seed moisture content, microwave power, air temperature and exposure time significantly affected the seed moisture loss, whereas, seed moisture content being most effective factor followed by exposure time. Additionally, microwave power had more contribution to moisture removal than the air temperature. According to Figure 4, (b) lentil seeds bed temperature was mostly affected by air temperature followed by microwave power, while other factors did not have any significant effect. Final lentil bed temperature is shown in Figure 5. The lentil seeds' bed temperature corresponded with increasing air temperature and microwave power. Its maximum value was $70^{\circ} \mathrm{C}$ at the power of $400 \mathrm{~W}$ for $18.5 \% \mathrm{MC}$ and $500 \mathrm{~W}$ for $10.5 \% \mathrm{MC}$ and air temperature of $60^{\circ} \mathrm{C}$. Lentil seeds' surface temperatures were different from the bed temperature as the bed temperature was an average of seed surface and air temperature.

a

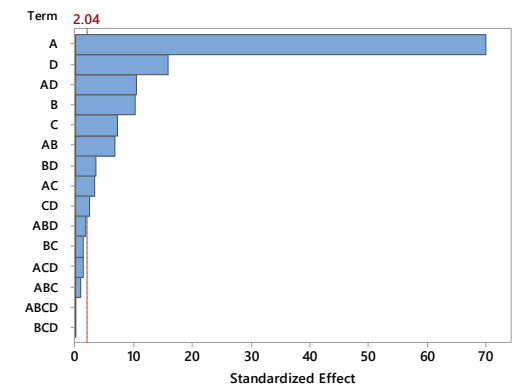

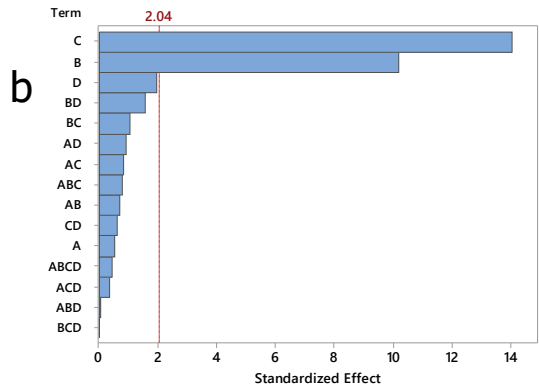

Figure 4 Pareto Chart of the standardized effects for (a) moisture loss and (b) bed temperature with $\mathrm{a}=0.05 ; \mathrm{A}=$ moisture content $(10.5 \%, 18.5 \%), \mathrm{B}=$ microwave power $(0,300,400 \mathrm{~W}$ for $18.5 \% \mathrm{MC}$ and $0,400,500 \mathrm{~W}$ for $10.5 \% \mathrm{MC}), \mathrm{C}=$ air temperature $(50$, $\left.60^{\circ} \mathrm{C}\right), \mathrm{D}=$ exposure time $(5,10 \mathrm{~min})$ 


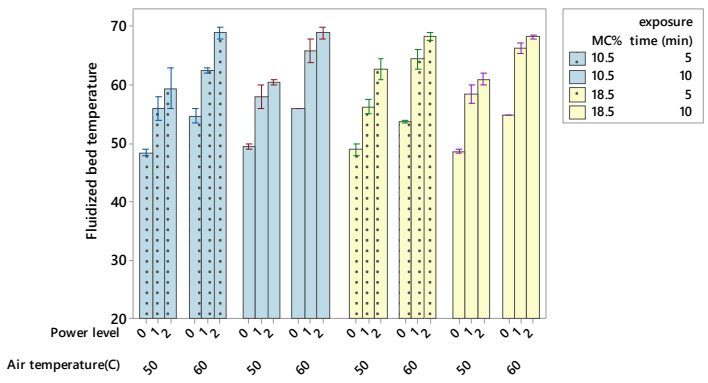

Figure 5 Final bed temperature at two set air temperatures of 50 and $60^{\circ} \mathrm{C}$, two exposure times of 5 and $10 \mathrm{~min}$, microwave powers of $0,300,400 \mathrm{~W}$ for $18.5 \% \mathrm{MC}$ (power level of $0,1,2$ respectively) and $0,400,500 \mathrm{~W}$ for $10.5 \% \mathrm{MC}$ (power level of $0,1,2$ respectively); bars are SE from the mean; MC-moisture content

Effect of microwave power, air temperature and exposure time on seed viability and percentage of infected lentil seeds at each seed moisture content as a categorical factor Generally, initial seed moisture content had by far the most influence on IS\% using general full factorial regression with $\mathrm{R}^{2}=79 \%, \mathrm{~F}-$ Value $=42.62$ and P-Value $=0.000$. Therefore, statistical analysis for seed viability and IS\% were carried out separately for each of moisture contents of $10.5 \%$ and $18.5 \%$. The Pareto chart of standardized effects for germination percentage and infected seeds percentage counted after 4 days (IS\%-4d) for treated lentil seeds at $18.5 \% \mathrm{MC}$ is shown in Figure 6, (a) and (b) respectively. Both microwave power and air temperature had a significant effect on seed germination and IS\%-4d. However, the effect of microwave power on IS\%-4d was more than the effect of air temperature, while they affect seed germination almost equally. According to the results of main effect plots for the seeds at $18.5 \% \mathrm{MC}$, IS\% decreased with increasing microwave power, air temperature and exposure time. Similarly, seed germination was negatively affected by increasing air temperature and microwave power from 300 to $400 \mathrm{~W}$, while increasing microwave power from 0 to 300 had a positive effect on seed germination. For $10.5 \% \mathrm{MC}$, the general factorial regression did not provide a good fit and hence, no conclusion was derived about the effect of process parameters on IS\% and seed viability. 

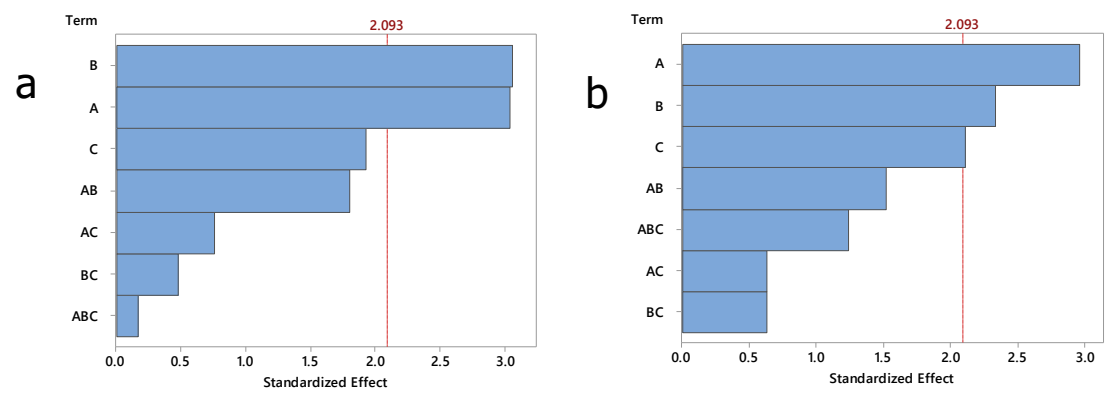

Figure 6 Pareto Chart of the standardized effects for (a) germination percentage and (b) infected seeds percentage counted after $4 \mathrm{~d}$ of lentil seeds at $18.5 \% \mathrm{MC} ; \mathrm{A}=$ microwave power $(0,300,400 \mathrm{~W}), \mathrm{B}=$ air set temperature $\left(50,60^{\circ} \mathrm{C}\right), \mathrm{C}=$ exposure time $(5,10 \mathrm{~min})$;

$$
\alpha=0.05
$$

Table 1 represents the results of germination percentage ( $\mathrm{G} \%)$, infected seeds percentage counted after 4 days (IS\% 4d) and 10 days (IS\% 10d), and electrical conductivity of soaking water (EC) after microwave fluidized bed treatments of lentil seeds at two moisture contents of $10.5 \%$ and $18.5 \%$ with exposure times of 5 and $10 \mathrm{~min}$. For seeds at $10.5 \% \mathrm{MC}$, none of the treatments affected germination, electrical conductivity or IS\%, even at bed temperature of close to $70^{\circ} \mathrm{C}$ (seed surface temperature of $75-80^{\circ} \mathrm{C}$ ), which was obtained by microwave power of $500 \mathrm{~W}$ and air temperature of $60^{\circ} \mathrm{C}$ and exposure time of $10 \mathrm{~min}$, while in the experiment with the water bath, the pathogen was eliminated at $75^{\circ} \mathrm{C}$. The difference between these results could stem from the difference between relative humidity $(\mathrm{RH})$ around the seeds at the time of treatments. Equilibrium RH around the seeds (water activity of the seeds) at $10.5 \% \mathrm{MC}$ at $60^{\circ} \mathrm{C}$ is between 60 to $75 \%$ (Menkov 2000) and as the water activity (and corresponding equilibrium $\mathrm{RH}$ ) of the carbohydrate/protein rich foods increases by increasing temperature (Syamaladevi, Tang et al. 2016), RH of the seeds sealed in the bag in the water bath at $10.5 \% \mathrm{MC}$ and temperature of $75^{\circ} \mathrm{C}$ will be more than $60 \%$. However, in microwave fluidized bed treatments, RH of air at the mentioned speed and temperature of $60{ }^{\circ} \mathrm{C}$ was measured as $11 \%$, when ambient $\mathrm{RH}$ was about $50 \%$, and this amount can be even less when the microwave is also used in combination with hot air. Therefore, the very low $\mathrm{RH}$ in the microwave fluidized bed could be the reason for increasing the lethal temperature of the seed pathogen. The other reason, which was mentioned by Syamaladevi, Tang et al. (2016), might be very fast desiccation of the pathogen in the microwave fluidized bed which could increase the pathogen's resistance to irreversible damage due to high temperatures.

Results for seeds with $18.5 \% \mathrm{MC}$ showed that by applying microwave power of $300 \mathrm{~W}$ and air temperature of $60^{\circ} \mathrm{C}$ for $10 \mathrm{~min}$, IS\% counted after $10 \mathrm{~d}(\mathrm{IS} \%-10 \mathrm{~d})$ reduced from $82 \%$ to $55 \%$ without any significant loss of viability. IS $\%$ - $10 \mathrm{~d}$ was reduced from $82 \%$ to $51.6 \%$ by applying microwave power of $400 \mathrm{~W}$ and air temperature of $60^{\circ} \mathrm{C}$ for $10 \mathrm{~min}$; however, germination was also decreased from $95 \%$ to $60 \%$. No significant change in electrical conductivity was observed as a result of these treatments. Here again, the difficulty of eliminating the seed pathogen could be related to the lower RH around the seeds. Nevertheless, it was more feasible to reduce the pathogen's load at higher MC of $18.5 \%$ than the dry seeds.

BGM pathogen growth on the seeds in BSM was evaluated on day 4 and 10, as after 4 days the pathogen mycelium, as well as the separated brown areas on BSM (tannin oxidation) were clearly discriminated and were comparable with the non-treated seeds. After 10 days, the mycelial growth was more and IS\% in almost all the plates, including the control. The 
difference between the treated and control samples was less than that on day 4 . After 2 weeks of incubation, conidia were observed on the mycelium, however, the mycelium grew beyond the initially contaminated seeds and also infected healthy lentil seeds. Conclusively, reduction of IS\% was considered after 4 (start of the growth) and 10 days (when healthy seeds could still be separated).

\section{Conclusion}

Microwave fluidized bed processing method was developed in this study to evaluate its potential for eradication of BGM pathogen from lentil seeds. The effect of process parameters on moisture loss, bed temperature, seed germination and infected seed percentage (IS\%) were investigated. Most effective factors on moisture loss and bed temperature were seed moisture content and air temperature, respectively and microwave power was the most effective factor in IS\% reduction. Air temperature and microwave power equally affected seed germination. Additionally, it was observed that eradication of BGM pathogen from lentil seeds in a microwave fluidized bed was more difficult than doing this in a sealed polyethylene bag in a water bath at the same temperature, which was concluded to be due to the difference in RH of the air around the seeds at the time of treatment. It is therefore recommended to investigate the effect of increasing RH of inlet air on seed pathogen reduction in future studies. BGM pathogen reduction, without significant seed viability loss in a microwave fluidized bed, was obtained by applying microwave power of $300 \mathrm{~W}$ and set air temperature of $60^{\circ} \mathrm{C}$ on seeds with a moisture content of $18.5 \%$ for $10 \mathrm{~min}$. This gave a $27 \%$ reduction in IS\% from $82 \%$ to $55 \%$. Therefore, microwave fluidized bed dryer can be considered as part of integrated disease management of BGM of lentil if the seed moisture content and process parameters are standardized for effective irradiation of the pathogen inoculum from the lentil seeds. 


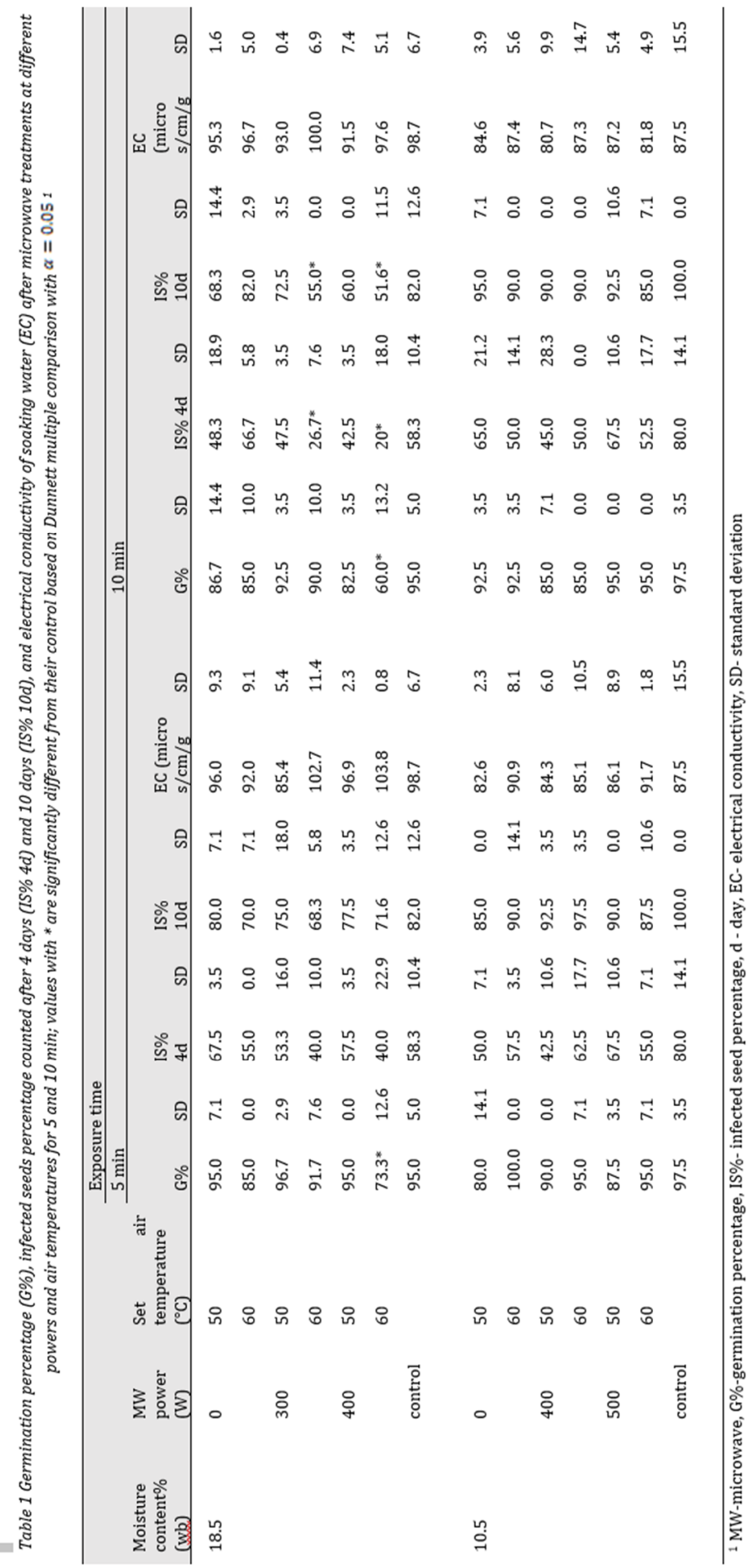




\section{References}

Beniwal, S. and A. Trapero-Casas (1994). Integrated control of diseases of cool season food legumes. Expanding the Production and Use of Cool Season Food Legumes, Springer: 642665 .

Burgess, D., T. Bretag and P. Keane (1997). "Biocontrol of seedborne Botrytis cinerea in chickpea with Gliocladium roseum." Plant Pathology 46(3): 298-305.

Burgess, D. R. (1997). "Seed-to-seedling transmission of Botrytis cinerea in chickpea and disinfestation of seed with moist heat." Australian journal of experimental agriculture 37(2). Edwards, S. and B. Seddon (2001). "Selective media for the specific isolation and enumeration of Botrytis cinerea conidia." Letters in applied microbiology 32(2): 63-66.

Fillinger, S. and Y. Elad (2016). Botrytis: The Fungus, the Pathogen and Its Management in Agricultural Systems, Springer.

Gharibzahedi, S. M. T., M. Ghahderijani and Z. S. Lajevardi (2014). "Specific heat, thermal conductivity and thermal diffusivity of red lentil seed as a function of moisture content." Journal of Food Processing and Preservation 38(4): 1807-1811.

ISTA ( 2016). International Rules for Seed Testing Zürichstr. 50, CH-8303 Bassersdorf, Switzerland, International Seed Testing Association.

Lindbeck, K., T. Bretag and R. Ford (2009). "Survival of Botrytis spp. on infected lentil and chickpea trash in Australia." Australasian Plant Pathology 38(4): 399-407.

Lindbeck, K. D., T. W. Bretag and M. A. Materne (2008). "Field screening in Australia of lentil germplasm for resistance to botrytis grey mould." Australasian Plant Pathology 37(4): 373-378.

Marquenie, D., J. Lammertyn, A. H. Geeraerd, C. Soontjens, J. F. Van Impe, B. M. Nicolaï and C. W. Michiels (2002). "Inactivation of conidia of Botrytis cinerea and Monilinia fructigena using UV-C and heat treatment." International Journal of Food Microbiology 74(1): 27-35.

Menkov, N. D. (2000). "Moisture sorption isotherms of lentil seeds at several temperatures." Journal of Food Engineering 44(4): 205-211.

Syamaladevi, R. M., J. Tang, R. Villa-Rojas, S. Sablani, B. Carter and G. Campbell (2016). "Influence of water activity on thermal resistance of microorganisms in low-moisture foods: a review." Comprehensive Reviews in Food Science and Food Safety 15(2): 353-370.

Taheri, S., G. Brodie, M. V. Jacob and E. Antunes (2018). "Dielectric properties of chickpea, red and green lentil in the microwave frequency range as a function of temperature and moisture content." Journal of Microwave Power and Electromagnetic Energy: 1-17.

Taheri, S., G. I. Brodie, D. Gupta and R. H. R. Dadu (2019). "Effect of Microwave Radiation on Internal Inoculum of Ascochyta Blight in Lentil Seeds at Different Seed Moisture Contents." Transactions of the ASAE 62(1): 33-43.

Tang, J. and S. Sokhansanj (1991). "Determination of moisture content of whole kernel lentil by oven method." Transactions of the ASAE 34(1): 255-0256.

Tang, J., S. Sokhansanj, S. Yannacopoulos and S. Kasap (1991). "Specific heat capacity of lentil seeds by differential scanning calorimetry." Transactions of the ASAE 34(2): 5170522.

Yigal Elad, B. W., Paul Tudzynski, Nafiz Delen (2007). "Botrytis: Biology, Pathology and Control." 